\title{
Quality of life before and after bariatric surgery
}

\author{
Qualidade de vida antes e após a cirurgia bariátrica
}

\author{
Josiane da Motta Moraes ${ }^{1}$ \\ Rita Catalina Aquino Caregnato ${ }^{1,2}$ \\ Daniela da Silva Schneider ${ }^{1}$
}

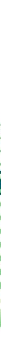

\section{Keywords}

Quality of life/psychology; Bariatric surgery; Obesity, morbid/surgery; Obesity, morbid/psychology; Questionnaires

Descritores

Qualidade de vida/psicologia; Cirurgia bariátrica; Obesidade mórbida/ cirurgia; Obesidade mórbida/psicologia;

Questionários

Submitted February 4, 2014

Accepted April 14, 2014

\section{Corresponding author}

Daniela da Silva Schneider

Sarmento Leite street, 245, Porto

Alegre, RS, Brazil.

Zip Code: 90050-170

daniela@schneider.inf.br

\section{DOI}

http://dx.doi.org/10.1590/1982-

0194201400028

\begin{abstract}
Objective: Knowing the quality of life of obese patients before and after bariatric surgery.

Methods: A cross-sectional and prospective study that included 16 obese patients who underwent bariatric surgery. The survey instrument was the Whogol-bref translated and validated for the Portuguese language. Data were collected before and after the bariatric surgery. The SPSS 19.0 was used for data analysis with application of the McNemar's test for related samples, considering $p<0.05$ significant.

Results: Before surgery $25 \%$ of participants considered their quality of life and health as bad or very bad, showing dissatisfaction. After surgery, all assessed their quality of life and satisfaction with health as good or very good. The percentages found in relation to negative feelings were better; it was observed that $62.5 \%$ did not express negative feelings anymore or only sometimes had these feelings.

Conclusion: The results showed that the quality of life, health, feelings, satisfaction and ability to do things has improved after bariatric surgery.
\end{abstract}

Resumo

Objetivo: Conhecer a qualidade de vida antes e após a cirurgia bariátrica.

Métodos: Estudo transversal e prospectivo que incluiu 16 obesos que se submeteram à cirurgia bariátrica. 0 instrumento de pesquisa foi o Whoqol-bref traduzido e validado para língua portuguesa. Os dados foram coletados antes e após a cirurgia bariátrica. Para a análise dos dados utilizou-se o Software SPSS 19.0 com aplicação do teste Mc Nemar para amostras relacionadas, considerando-se como significativo $p<0,05$.

Resultados: Antes da cirurgia, 25\% consideraram a qualidade de vida e saúde ruim ou muito ruim, mostrandose insatisfeitos. Depois da cirurgia, todos avaliaram a qualidade de vida e satisfação com a saúde como boa ou muito boa. Os percentuais encontrados em relação aos sentimentos negativos melhoraram; observou-se que $62,5 \%$ manifestaram não ter mais, ou apenas sentir algumas vezes, sentimentos negativos.

Conclusão: Os resultados mostraram que a qualidade de vida, saúde, sentimentos, satisfação e capacidade de realizar coisas melhoraram após a cirurgia bariátrica.

\footnotetext{
'Universidade Luterana do Brasil, Canoas, RS, Brazil.

2Universidade Federal de Ciências da Saúde, Porto Alegre, RS, Brazil.

Conflicts of interest: no conflicts of interest to declare.
} 


\section{Introduction}

Considered a global epidemic, obesity is a chronic disease of metabolic and/or genetic origin related to excess body fat, which can trigger conditions such as diabetes; cardiovascular diseases such as hypertension, myocardial infarction, thrombosis, embolism and arteriosclerosis; orthopedic problems; asthma; sleep apnea; some cancers; hepatic steatosis and psychological disorders. ${ }^{(1-3)}$ Therefore, the increase in body weight is associated with many comorbidities. ${ }^{(4)}$

Overweight and obesity have increased in the last six years in Brazil. The proportion of overweight people increased from $42.7 \%$ in 2006 to $48.5 \%$ in 2011 ; the percentage of obese also rose from $11.4 \%$ to $15.8 \%$. ${ }^{(4)}$ This growth tends to decline over the next ten years. This scenario has set a great impact on public health and costs associated with obesity treatments. ${ }^{(5)}$

The Body Mass Index is determined by dividing the individual's weight (in kilograms) by the square of the height (in meters). Underweight is defined when this value is less than 18.5; ideal weight is any value between 18.5 and 24.90; overweight is between 25 and 29.90; obesity is between 30 and 34.9; severe obesity between 35 and 39.9; and morbid obesity is any value greater than $40 .{ }^{(6)}$

There is evidence that moderate weight loss (5$10 \%$ of initial weight) with conventional treatment by nutritional and pharmacological approaches plus physical activity, promotes metabolic benefits. However, for the treatment and management of morbid obesity, the most effective tool is surgical intervention. ${ }^{(1,2,7)}$ The surgical procedure results in significant and lasting weight loss, preventing complications that threaten the quality of life, improving comorbidities and increasing longevity.

Quality of life is a multidimensional and subjective construct, which complicates its definition. The perception of individuals of their position in sociocultural context, including their goals, expectations, standards and concerns is an important aspect in the evaluation. It is closely related to personal wellbeing and covers aspects such as the health condition, leisure, personal satisfaction, and lifestyle habits. ${ }^{(8)}$
Hence, bariatric surgery can improve quality of life because it facilitates the body locomotion, decreases psychosocial and self-esteem damages, avoiding chronic and metabolic diseases. ${ }^{(3,9)}$

The preparation of patients for bariatric surgery requires adequate involvement of a multidisciplinary team, both in the pre-operative and post-operative periods, conducting the diagnostic evaluation and appropriate treatment, individual, marital or family therapy, with specific guidelines about the surgery, in order to discuss and adjust the patient's expectations to the limitations of surgical treatment. $^{(10)}$

Patients undergoing bariatric surgery should be prepared for nutritional education, reducing the amount of food ingested for lasting weight loss, and be aware of possible complications resulting from surgery. ${ }^{(7,11)}$ The reduction of the stomach can present major risks to compulsive patients, leading to psychological disorders. ${ }^{(9)}$

This study aimed at knowing the quality of life of obese patients before and after bariatric surgery.

\section{Methods}

This is a prospective cross-sectional study on the quality of life of patients in the pre and postoperative periods of bariatric surgery.

The research site was the clinic of a private hospital located in a municipality in the countryside of the state of Rio Grande do Sul, southern Brazil. The clinic, called "Espaço Vida" offers laboratory tests, ultrasound and bone densitometry, nursing care services, and has an amphitheater and a meeting room, where guidance and advising are done before and after bariatric surgery.

The sample was intentional of 16 morbidly obese patients who would be undergoing bariatric surgery with mixed surgical technique, which allows more restrictive component, comprising the various forms of gastric bypass with Roux-en-Y restoration of intestinal transit. Inclusion criteria were adults over 18 years, with indication of bariatric surgery and who attended multidisciplinary meetings to prepare for bariatric surgery. 
The survey instrument was the World Health Organization Quality of Life (Whoqol-bref) translated and validated for the Portuguese language, which covers the complexity of the construct and interrelates the environment with physical and psychological aspects, level of independence, social relationships and personal beliefs. ${ }^{(11)}$ The instrument consists of 26 questions, the first concerning the quality of life in general, and the second concerns the satisfaction with one's own health. The other 24 are divided into physical and psychological domains, and also domains of social relationships and environment relations. This instrument can be used for both healthy populations and for populations with chronic diseases and injuries. Besides the transcultural character, it values the individual perception and assesses the quality of life in many groups and situations. ${ }^{(11)}$

The data collection was carried out at the completion of multidisciplinary meetings to prepare for surgery and three months after surgery.

The frequency analysis was done, as well as the results of continuous variables as mean \pm standard deviation. The McNemar's test was used for related samples noting the significance of changes applicable to experiments of the 'before and after' type. In order to verify the normality of data was used the Kolmogorov-Smirnov test, and values of $\mathrm{p}<0.05$ were considered significant. Data analysis was done with the SPSS 19.0.

The development of the study followed the national and international standards of ethics in research involving human beings.

\section{Results}

The time to complete the questionnaire was of 11 minutes before the surgery and seven minutes after the surgery; only one patient asked for help from a family member to complete the questionnaire in the preoperative period.

The study population consisted of women $(93.75 \%)$, married $(75 \%)$, four health professionals $(25 \%)$ - a nutritionist and three nursing technicians. The others were three self-employed profes- sionals, six people with complete high school and two students.

Table 1 shows the results of quality of life, health, feelings and satisfaction of the morbidly obese expressed by respondents before and after bariatric surgery through frequency analysis.

It was found that, prior to surgery $25 \%$ considered their quality of life and health as bad or very bad, showing dissatisfaction. After surgery, all of them assessed the quality of life and satisfaction with their health as good or very good. The percentages found in relation to negative feelings were better; it was observed that after the surgery $62.5 \%$ did not express negative feelings anymore or only sometimes had these feelings such as, bad mood, despair, anxiety and depression.

It was observed that the majority showed an intermediate position when answering about the feelings they had in the two previous weeks; after surgery the majority $(81.25 \%)$ reported no pain or very little pain when doing physical activities, 93.75\% expressed to be enjoying life more. It is noteworthy that $100 \%$ expressed having found meaning in life after the surgery. Also, in the items of safety, concentration and health in the physical environment, they answered to be quite pleased.

Regarding satisfaction expressed in the last two weeks of the pre-operative period, it was identified that the majority $(68.75 \%)$ did not physically accept themselves and that $68.75 \%$ had no opportunity to do leisure activities. The only variable that did not change postoperatively was having enough money.

Table 2 shows the frequency analysis of the opinion of morbidly obese patients in relation to their ability to perform.

Before surgery, 50\% responded feeling difficulty in performing everyday life activities. It was observed that the most participants (68.75\%) found themselves satisfied with social relationships; $75 \%$ said they were satisfied or very satisfied with the support and the place of residence, and $81.25 \%$ reported to have access to services.

Regarding the ability to do things, it became evident in the postoperative period that the majority was satisfied. 
Table 1. Quality of life, health, feelings and satisfaction before and after bariatric surgery

\begin{tabular}{|c|c|c|c|c|c|}
\hline \multicolumn{6}{|c|}{ Evaluation } \\
\hline Before & $\begin{array}{l}\text { Very bad } \\
\mathrm{n}(\%)\end{array}$ & $\begin{array}{l}\text { Bad } \\
n(\%)\end{array}$ & $\begin{array}{l}\text { Neither bad nor good } \\
n(\%)\end{array}$ & $\begin{array}{l}\text { Good } \\
n(\%)\end{array}$ & $\begin{array}{l}\text { Very good } \\
\mathrm{n}(\%)\end{array}$ \\
\hline Assessment of quality of life & $1(6.25)$ & $3(18.75)$ & $6(37.5)$ & $6(37.5)$ & $0(0)$ \\
\hline \multirow[t]{2}{*}{ Satisfaction with health } & $\begin{array}{l}\text { Very dissatisfied } \\
n(\%)\end{array}$ & $\begin{array}{l}\text { Dissatisfied } \\
n(\%)\end{array}$ & $\begin{array}{l}\text { Neither satisfied nor dissatisfied } \\
\qquad n(\%)\end{array}$ & $\begin{array}{l}\text { Satisfied } \\
n(\%)\end{array}$ & $\begin{array}{l}\text { Very satisfied } \\
n(\%)\end{array}$ \\
\hline & $1(6.25)$ & $3(18.75)$ & $6(37.5)$ & $6(37.5)$ & $0(0)$ \\
\hline \multirow[t]{2}{*}{$\begin{array}{l}\text { Frequency of negative feelings such as bad mood, } \\
\text { despair, anxiety, depression }\end{array}$} & $\begin{array}{c}\text { Never } \\
n(\%)\end{array}$ & $\begin{array}{c}\text { Sometimes } \\
n(\%)\end{array}$ & $\begin{array}{l}\text { Frequently } \\
\mathrm{n}(\%)\end{array}$ & $\begin{array}{l}\text { Very frequently } \\
\quad \mathrm{n}(\%)\end{array}$ & $\begin{array}{c}\text { Always } \\
\mathrm{n}(\%)\end{array}$ \\
\hline & $0(0)$ & $6(37.5)$ & $3(18.75)$ & $6(37.5)$ & $1(6.25)$ \\
\hline After & $\begin{array}{l}\text { Very bad } \\
\mathrm{n}(\%)\end{array}$ & $\begin{array}{l}\text { Bad } \\
n(\%)\end{array}$ & $\begin{array}{l}\text { Neither bad nor good } \\
\qquad(\%)\end{array}$ & $\begin{array}{l}\text { Good } \\
\mathrm{n}(\%)\end{array}$ & $\begin{array}{l}\text { Very good } \\
\mathrm{n}(\%)\end{array}$ \\
\hline Assessment of quality of life & $0(0)$ & $0(0)$ & $0(0)$ & $5(31.25)$ & $11(68.75)$ \\
\hline \multirow[t]{2}{*}{ Satisfaction with health } & $\begin{array}{l}\text { Very dissatisfied } \\
\mathrm{n}(\%)\end{array}$ & $\begin{array}{l}\text { Dissatisfied } \\
\mathrm{n}(\%)\end{array}$ & $\begin{array}{l}\text { Neither satisfied nor dissatisfied } \\
\qquad \mathrm{n}(\%)\end{array}$ & $\begin{array}{c}\text { Satisfied } \\
n(\%)\end{array}$ & $\begin{array}{l}\text { Very satisfied } \\
n(\%)\end{array}$ \\
\hline & $0(0)$ & $0(0)$ & $0(0)$ & $7(43.75)$ & $9(56.25)$ \\
\hline \multirow[t]{2}{*}{$\begin{array}{l}\text { Frequency of negative feelings such as bad mood, } \\
\text { despair, anxiety, depression }\end{array}$} & $\begin{array}{l}\text { Never } \\
n(\%)\end{array}$ & $\begin{array}{l}\text { Sometimes } \\
n(\%)\end{array}$ & $\begin{array}{l}\text { Frequently } \\
\mathrm{n}(\%)\end{array}$ & $\begin{array}{l}\text { Very frequently } \\
\quad n(\%)\end{array}$ & $\begin{array}{l}\text { Always } \\
\mathrm{n}(\%)\end{array}$ \\
\hline & $4(25)$ & $6(37.5)$ & $1(6.25)$ & $4(25)$ & $1(6.25)$ \\
\hline Before & $\begin{array}{l}\text { None } \\
n(\%)\end{array}$ & $\begin{array}{l}\text { Very little } \\
\mathrm{n}(\%)\end{array}$ & $\begin{array}{l}\text { More or less } \\
\quad \mathrm{n}(\%)\end{array}$ & $\begin{array}{l}\text { Very much } \\
\mathrm{n}(\%)\end{array}$ & $\begin{array}{l}\text { Extremely } \\
\mathrm{n}(\%)\end{array}$ \\
\hline Impediment of activities because of physical pain & $0(0)$ & $1(6.25)$ & $7(43.75)$ & $7(43.75)$ & $1(6.25)$ \\
\hline Need for medical treatment to lead the daily life & $2(12.5)$ & $3(18.75)$ & $6(37.5)$ & $4(25)$ & $1(6.25)$ \\
\hline Enjoyment of life & $0(0)$ & $4(25)$ & $8(50)$ & $4(25)$ & $0(0)$ \\
\hline Meaning of life & $2(12.5)$ & $0(0)$ & $6(37.5)$ & $5(31.25)$ & $3(18.75)$ \\
\hline Amount of concentration & $1(6.25)$ & $2(12.5)$ & $8(50)$ & $4(25)$ & $1(6.25)$ \\
\hline Security in life & $1(6.25)$ & $2(12.5)$ & $9(56.25)$ & $3(18.75)$ & $1(6.25)$ \\
\hline $\begin{array}{l}\text { Health of physical environment (climate, noise, pollution, } \\
\text { leisure) }\end{array}$ & $0(0)$ & $2(12.5)$ & $10(62.5)$ & $3(18.75)$ & $1(6.25)$ \\
\hline After & $\begin{array}{l}\text { None } \\
n(\%)\end{array}$ & $\begin{array}{l}\text { Very little } \\
n(\%)\end{array}$ & $\begin{array}{l}\text { More or less } \\
\quad n(\%)\end{array}$ & $\begin{array}{l}\text { Very much } \\
\mathrm{n}(\%)\end{array}$ & $\begin{array}{l}\text { Extremely } \\
n(\%)\end{array}$ \\
\hline Impediment of activities because of physical pain & $5(31.25)$ & $8(50)$ & $2(12.5)$ & $1(6.25)$ & $0(0)$ \\
\hline Need for medical treatment to lead the daily life & $4(25)$ & $6(37.50)$ & $5(31.25)$ & $1(6.25)$ & $0(0)$ \\
\hline Enjoyment of life & $0(0)$ & $0(0)$ & $1(6,25)$ & $13(81.25)$ & $2(12.5)$ \\
\hline Meaning of life & $0(0)$ & $0(0)$ & $0(0)$ & $8(50)$ & $8(50)$ \\
\hline Amount of concentration & $0(0)$ & $0(0)$ & $4(25)$ & $11(68.75)$ & $1(6.25)$ \\
\hline Security in life & $0(0)$ & $0(0)$ & $2(12.5)$ & $11(68.75)$ & $3(18.75)$ \\
\hline $\begin{array}{l}\text { Health of physical environment (climate, noise, pollution, } \\
\text { leisure) }\end{array}$ & $0(0)$ & $3(18.75)$ & $3(18.75)$ & $8(50)$ & $2(12.50)$ \\
\hline Before & $\begin{array}{l}\text { Nothing } \\
\mathrm{n}(\%)\end{array}$ & $\begin{array}{l}\text { Very little } \\
\mathrm{n}(\%)\end{array}$ & $\begin{array}{c}\text { Average } \\
\mathrm{n}(\%)\end{array}$ & $\begin{array}{l}\text { Very much } \\
\mathrm{n}(\%)\end{array}$ & $\begin{array}{l}\text { Completely } \\
\mathrm{n}(\%)\end{array}$ \\
\hline Enough energy for daily living & $1(6.25)$ & $4(25)$ & $10(62.5)$ & $1(6.25)$ & $0(0)$ \\
\hline Acceptance of physical appearance & $5(31.25)$ & $6(37.5)$ & $2(12.5)$ & $3(18.75)$ & $0(0)$ \\
\hline Enough money to meet the needs & $0(0)$ & $4(25)$ & $11(68.75)$ & $1(6.25)$ & $0(0)$ \\
\hline Availability of information needed in day by day & $0(0)$ & $2(12.5)$ & $5(31.25)$ & $6(37.5)$ & $3(18.75)$ \\
\hline Opportunity to do leisure activity & $0(0)$ & $11(68.75)$ & $5(31.25)$ & $0(0)$ & $0(0)$ \\
\hline After & $\begin{array}{l}\text { Nothing } \\
n(\%)\end{array}$ & $\begin{array}{l}\text { Very little } \\
n(\%)\end{array}$ & $\begin{array}{l}\text { Average } \\
\mathrm{n}(\%)\end{array}$ & $\begin{array}{l}\text { Very much } \\
\mathrm{n}(\%)\end{array}$ & $\begin{array}{l}\text { Completely } \\
\mathrm{n}(\%)\end{array}$ \\
\hline Enough energy for daily living & $0(0)$ & $0(0)$ & $5(31.25)$ & $7(43.75)$ & $4(25)$ \\
\hline Acceptance of physical appearance & $0(0)$ & $0(0)$ & $1(6.25)$ & $4(25)$ & $11(68.75)$ \\
\hline Enough money to meet the needs & $0(0)$ & $2(12.5)$ & $10(62.5)$ & $2(12.5)$ & $2(12.5)$ \\
\hline Availability of information needed in day by day & $1(6.25)$ & $0(0)$ & $2(12.5)$ & $10(62.5)$ & $3(18.75)$ \\
\hline Opportunity to do leisure activity & $0(0)$ & $2(12.5)$ & $5(31.25)$ & $7(43.75)$ & $2(12.5)$ \\
\hline
\end{tabular}


Table 2. Ability to perform

\begin{tabular}{|c|c|c|c|c|c|}
\hline Variables & $\begin{array}{c}\text { Very bad } \\
\mathrm{n}(\%)\end{array}$ & $\begin{array}{c}\text { Bad } \\
n(\%)\end{array}$ & $\begin{array}{l}\text { Neither bad } \\
\text { nor good } \\
\text { n(\%) }\end{array}$ & $\begin{array}{l}\text { Good } \\
\mathrm{n}(\%)\end{array}$ & $\begin{array}{l}\text { Very good } \\
\mathrm{n}(\%)\end{array}$ \\
\hline \multicolumn{6}{|l|}{ Before surgery } \\
\hline Mobility & $0(0)$ & $7(43.75)$ & $3(18.75)$ & $6(37.5)$ & $0(0)$ \\
\hline Satisfaction in relation to sleep & 1(6.25) & $1(6.25)$ & $10(62.5)$ & $4(25)$ & $0(0)$ \\
\hline Satisfaction with the ability to perform day-to-day activities & $0(0)$ & $8(50)$ & $5(31.25)$ & $2(12.5)$ & $1(6.25)$ \\
\hline Satisfaction with the ability to perform work. & $0(0)$ & $7(43.75)$ & $4(25)$ & $3(18.75)$ & $2(12.5)$ \\
\hline Self-satisfaction & 2(12.5) & $5(31.25)$ & $7(43.75)$ & $1(6.25)$ & $1(6.25)$ \\
\hline Satisfaction with personal relationships (friends, relatives, acquaintances, colleagues) & $0(0)$ & $1(6.25)$ & $4(25)$ & $6(37.5)$ & $5(31.25)$ \\
\hline Satisfaction with sex life & $3(18.75)$ & $1(6.25)$ & $7(43.75)$ & $3(18.75)$ & $2(12.5)$ \\
\hline Satisfaction with the support received from friends & $0(0)$ & $1(6.25)$ & $3(18.75)$ & $5(31.25)$ & $7(43.75)$ \\
\hline Satisfaction with the conditions of the place of residence & $1(6.25)$ & $1(6.25)$ & $2(12.5)$ & $5(31.25)$ & $7(43.75)$ \\
\hline Satisfaction with access to health services & $0(0)$ & $1(6.25)$ & $2(12.5)$ & $8(50)$ & $5(31.25)$ \\
\hline Satisfaction with means of transportation & $0(0)$ & $1(6.25)$ & $4(25)$ & $8(50)$ & $3(18.75)$ \\
\hline \multicolumn{6}{|l|}{ After surgery } \\
\hline Mobility & $0(0)$ & $0(0)$ & $0(0)$ & $5(31.25)$ & $11(68.75)$ \\
\hline Satisfaction in relation to sleep & $0(0)$ & $0(0)$ & $3(18.75)$ & $6(37.5)$ & $7(43.75)$ \\
\hline Satisfaction with the ability to perform day-to-day activities & $0(0)$ & $1(6.25)$ & $0(0)$ & $6(37.5)$ & $9(56.25)$ \\
\hline Satisfaction with the ability to perform work & $0(0)$ & $0(0)$ & $1(6.25)$ & $5(31.25)$ & 10(62.50) \\
\hline Self-satisfaction & $0(0)$ & $0(0)$ & $4(25)$ & $3(18.75)$ & 9(56.25) \\
\hline Satisfaction with personal relationships (friends, relatives, acquaintances, colleagues) & $0(0)$ & $0(0)$ & 2(12.5) & $7(43.75)$ & $7(43.75)$ \\
\hline Satisfaction with sex life & $0(0)$ & $1(6.25)$ & $2(12.5)$ & $7(43.75)$ & $6(37.5)$ \\
\hline Satisfaction with the support received from friends & $0(0)$ & $0(0)$ & $0(0)$ & $7(43.75)$ & 9(56.25) \\
\hline Satisfaction with the conditions of the place of residence & $1(6.25)$ & $0(0)$ & $1(6.25)$ & $7(43.75)$ & $7(43.75)$ \\
\hline Satisfaction with access to health services & $0(0)$ & $0(0)$ & $0(0)$ & $11(68.75)$ & $5(31.25)$ \\
\hline Satisfaction with means of transportation & $0(0)$ & $0(0)$ & $0(0)$ & $8(50)$ & $8(50)$ \\
\hline
\end{tabular}

The comparison between the level of satisfaction before and after surgery is shown in table 3 . In order to investigate the association between the level of satisfaction before and after surgery was used the McNemar's test, indicated for related samples and considered significant with p-value $<0.05$.

Table 1 shows many variables with statistically significant association in relation to patient satisfaction when comparing the opinions expressed in the preoperative and postoperative periods. The percentage of patients' satisfaction before surgery was $63.22 \%$, and after surgery it was $81.01 \%(\mathrm{p}=0.001)$.

\section{Discussion}

The limits of the study results are related to the cross-sectional design that does not allow establishing relations of cause and effect. On the other hand, all 16 bariatric surgeries performed at the study site were included in the analysis (100\%). Bariatric surgery brings many changes in the lives of obese, hence monitoring is important for adaptation and adherence to treatment.

The results showed that respondents judged to have improved their quality of life and health after surgery. Studies have shown that after bariatric sur- 
Table 3. Evaluation of patient satisfaction before and after bariatric surgery

\begin{tabular}{|c|c|c|c|}
\hline \multirow[b]{2}{*}{ Variables } & \multicolumn{2}{|c|}{ Percentage of satisfaction in surgery } & \multirow[b]{2}{*}{$\mathrm{p}$-value } \\
\hline & $\begin{array}{c}\text { Before } \\
\%\end{array}$ & $\begin{array}{c}\text { After } \\
\%\end{array}$ & \\
\hline \multicolumn{4}{|l|}{ Quality of life and health } \\
\hline Assessment of quality of life & 37.50 & 100.00 & 0.01 \\
\hline Satisfaction with health & 37.50 & 100.00 & 0.01 \\
\hline \multicolumn{4}{|l|}{ Feelings in the two previous weeks } \\
\hline Impediment of activities because of physical pain & 50.00 & 81.25 & 0.02 \\
\hline Need for medical treatment to lead the daily life & 31.25 & 62.50 & 0.08 \\
\hline Enjoyment of life & 25.00 & 93.75 & 0.01 \\
\hline Meaning of life & 50.00 & 100.00 & 0.01 \\
\hline Amount of concentration & 31.25 & 75.00 & 0.21 \\
\hline Security in life & 25.00 & 87.50 & 0.01 \\
\hline Health of physical environment (climate, noise, pollution, leisure) & 25.00 & 62.50 & 0.03 \\
\hline \multicolumn{4}{|l|}{ Satisfaction in the two previous weeks } \\
\hline Enough energy for daily living & 6.25 & 68.75 & 0.04 \\
\hline Acceptance of physical appearance & 18.75 & 93.75 & 0.03 \\
\hline Enough money to meet the needs & 6.25 & 25.00 & 0.08 \\
\hline Availability of information needed in day by day & 56.25 & 81.25 & 0.27 \\
\hline Ability to do things & 37.50 & 100.00 & 0.03 \\
\hline \multicolumn{4}{|l|}{ Mobility } \\
\hline Satisfaction in relation to sleep. & 25.00 & 81.25 & 0.01 \\
\hline Satisfaction with the ability to perform day-to-day activities & 18.75 & 93.75 & 0.02 \\
\hline Satisfaction with the ability to perform work. & 31.25 & 93.75 & 0.18 \\
\hline Self-satisfaction & 12.50 & 75.00 & 0.02 \\
\hline \multicolumn{4}{|l|}{ Satisfaction with personal relationships (friends, relatives, acquaintances, colleagues) } \\
\hline Satisfaction with sex life & 31.25 & 81.25 & 0.01 \\
\hline Satisfaction with the support received from friends & 75.00 & 100.00 & 0.08 \\
\hline Satisfaction with the conditions of the place of residence & 75.00 & 87.50 & 0.58 \\
\hline Satisfaction with access to health services & 81.25 & 99.25 & 0.16 \\
\hline Satisfaction with means of transportation & 68.75 & 100.00 & 0.04 \\
\hline \multicolumn{4}{|l|}{ Negative feelings } \\
\hline Frequency of negative feelings such as bad mood, despair, anxiety, depression & 43.75 & 31.25 & 0.10 \\
\hline
\end{tabular}

gery there is a gradual decrease of body mass index, metabolic improvement, reduction of hypertension and type II diabetes mellitus. ${ }^{(7,12,13)}$

These results can contribute to the planning of nursing care before and after bariatric surgery, for health education and for coping with any complications.

Musculoskelatal pain in lower limbs decreased, and episodes of chronic pain also decreased after surgery. Several studies showed the same results. ${ }^{(14-18)}$

Regarding the variables related to satisfaction throughout the last two weeks, there was no difference before and after surgery only in the money aspect. For all the other variables - enough energy for the day, acceptance of physical appearance, availability of information and opportunity to do leisure activity - the result was satisfaction after surgery, highlighting that the majority showed acceptance in relation to their own physical appearance.

It was observed in this study, that after surgery all participants were satisfied with the ability to do things related to basic needs such as sleep, locomotion, sexual activity, interpersonal relationships and others. A study that used the International Index Erectile Function (IIEF) questionnaire for the investigation, concluded 
that two years after bariatric surgery, with reduced caloric intake and decreased body mass index, there was considerable improvement in the quality of sexual life. ${ }^{(1)}$

A study on the mobility of locomotion showed that the distance traveled by the obese was longer and with less pain after bariatric surgery. ${ }^{15)}$ This finding is in agreement with the results of this research, in which mobility was better after surgery.

Another research has shown that obese people were not happy with their bodies, did not enjoy going out and received unkind nicknames. (19) In this research, in the preoperative period, participants did not show satisfied nor dissatisfied with themselves; however, in relation to interpersonal relationships with colleagues, the majority reported feeling well.

A study on binge eating before and after bariatric surgery considered that the characteristics of compulsion, impaired emotional structure, anxiety, depression and difficulty in elaborating emotions should be considered risk factors for postoperative complications. ${ }^{(10)}$

A review study indicated improvement in clinical and functional conditions after bariatric surgery, but there was high prevalence of mental disorders in the population of bariatric patients, some with changes related to eating behavior, depressive syndromes, abuse of alcohol and other substances, anxiety and complications associated with impulsive behavior. ${ }^{(20)}$

The results showed that after bariatric surgery, $15(60 \%)$ out of the 25 studied variables were significant.

\section{Conclusion}

The results showed that the quality of life, health, feelings, satisfaction and ability to do things has improved after bariatric surgery.

\section{Acknowledgements}

We thank the institutional support received for the study, and Professor Dr. Karin Viegas for her collaboration.

\section{Collaborations}

Moraes JM; Caregnato RCA and Schneider DS participated in the project design, analysis and interpretation of data, critical review of the relevant intellectual content and final approval of the version to be published.

\section{References}

1. Araújo AA, Brito AM, Ferreira MN, Petribú K, Mariano MH. Modificações da qualidade de vida sexual de obesos submetidos à cirurgia de FobiCapella. Rev Col Bras Cir. 2009; 36(1):42-8.

2. Magdaleno-Júnior R, Chaim EA, Turato ER. Características psicológicas de pacientes submetidos à cirurgia bariátrica. Rev Psiquiatr Rio Grande do Sul. 2009;31(1):73-8.

3. Melo ME, Mancini MC. Obesidade como diagnosticar e tratar. Revista Brasileira de Medicina. São Paulo: Moreira Jr; 2009.

4. Brasil. Ministério da Saúde. Quase metade da população brasileira está acima do peso. Portal Saúde, 10 Abr. 2012 [citado 2013 Ago 18]. Disponível em: <http://portalsaude.saude.gov.br/portalsaude/ noticia/4718/162/quase-metade-da-populacao-brasileira-estaacima-do-peso.htm.

5. Mendes P. SUS gasta R $\$ 488$ mil em um ano com doenças ligadas à obesidade. Portal G1, 19 Mar. 2013 [citado 2013 Out 20]. Disponível em: $\quad<$ http://g1.globo.com/bemestar/noticia/2013/03/sus-gasta-r488-milhoes-por-ano-com-doencas-ligadas-obesidade.html.

6. Associação Brasileira para o Estudo da Obesidade e da Síndrome Metabólica. Diretrizes brasileiras de obesidade 2009/2010. 3a ed. Itapevi: AC Farmacêutica; 2009.

7. Pedrosa IV, Burgos MG, Souza NC. Morais CN. Aspectos nutricionais em obesos antes e após a cirurgia bariátrica. Rev Col Bras Cir. 2009;36(4):316-22.

8. Pucci GC, Rech CR, Fermino RC, Reis RS. Associação entre atividade física e qualidade de vida em adultos. Rev Saúde Pública. 2012; 46(1):166-79.

9. Leal CW, Baldin N. 0 impacto emocional da cirurgia bariátrica em pacientes com obesidade mórbida. Rev Psiquiatr Rio Grande do Sul. 2007; 29(3): 324-7.

10. Machado CE, Zilberstein B, Cecconello I, Monteiro M. Compulsão alimentar antes e após a cirurgia bariátrica. ABCD Arq Bras Cir Digestiva. 2008;21(4):185-91.

11. Kluthcovsky AC, Kluthcovsky FA. O WHOQOL-bref, um instrumento para avaliar qualidade de vida: uma revisão sistemática. Rev Psiquiatr Rio Grande do Sul. 2009; 31(3 Supl.)

12. Carvalho MV, Siqueira LB, Sousa ALL, Jardim PC. A influência da hipertensão arterial na qualidade de vida. Arq Bras Cardiol. 2013;100(2):164-74.

13. Forcina DV, Almeida BO, Ribeiro-Júnior MA. Papel da cirurgia bariátrica no controle do Diabete Melito Tipo II. ABCD Arq Bras Cir Digestiva. 2008;21(3):130-2.

14. Melo IT, São-Pedro M. Dor musculoesquelética em membros inferiores de pacientes obesos antes e depois da cirurgia bariátrica. ABCD Arq Bras Cir Digestiva. 2012;25(1):29-32. 
15. Soccol FB, Peruzzo SS, Mortari D, Scortegagna G, Sbruzzi G, Santos PC Rockenbach CW, Leguisamo CP. Prevalência de artralgia em indivíduos obesos no pré e pós-operatório tardio de cirurgia bariátrica. Scientia Medica. 2009;19(2):69-74.

16. Sá K, Baptista AF, Matos MA, Lessa I. Prevalência de dor crônica e fatores associados na população de Salvador, Bahia. Rev Bras Ortop. 2008;43(3):96-102.

17. Leveille SG, Zhang Y, McMullen W, Kelly-Hayes M, Felson D. Sex differences in musculoskeletal pain in older adults. Pain. 2005;3(116):332-8.
18. Wijhoven $\mathrm{H}$, De Vet $\mathrm{H}$, Picavet $\mathrm{S}$. Explaining sex differences in chronic musculoskeletal pain in general population. Pain. 2006;124(4):15866.

19. Serrano $A Q$, Vasconcelos MGL, Silva GA, Cerqueira MM, Pontes CM. Percepção do adolescente obeso sobre as repercussões da obesidade em sua saúde. Rev Esc Enferm USP; 2010;44(1):2531.

20. Gordon PC, Kaio GH, Sallet PC. Aspectos do acompanhamento psiquiátrico de pacientes obesos sob tratamento bariátrico: revisão. Rev Psiquiatr Clínica. 2011;38(4):148-54. 